\title{
NOTE
}

\section{Preliminary evidence on group-size dependent feeding success in the damselfish Dascyllus marginatus}

\author{
Rafi Kent ${ }^{1,2, *}$, Roi Holzman ${ }^{1}$, Amatzia Genin ${ }^{1}$ \\ ${ }^{1}$ The Interuniversity Institute for Marine Sciences of Eilat, and the Department of Evolution, Systematics and Ecology, \\ The Hebrew University of Jerusalem, PO Box 469, Eilat 88103, Israel \\ ${ }^{2}$ Present address: Department of Maritime Civilizations, Recanati Institute for Maritime Studies, Haifa University, \\ Mt. Carmel 31905, Israel
}

\begin{abstract}
The coral-reef damselfish Dascyllus marginatus forms social groups of up to 25 individuals per coral. The fish forage for drifting zooplankton while remaining close to their home coral, used as a shelter from predators. Therefore, enhanced crowding and, in turn, stronger competition for food is expected in larger groups. The number of fish per coral at our study site (Eilat, Red Sea) was significantly lower than that expected under random distribution, indicating the fish's preference to form small groups $(\leq 3$ ind.). The stomachs of fish in such groups contained, on average, twice as much food as those living in large groups ( $\geq 10$ ind.). These findings indicate that the cost of intragroup competition is substantial, possibly affecting group size in this species.
\end{abstract}

KEY WORDS: Intraspecific competition · Stomach content · Coral reef

Resale or republication not permitted without written consent of the publisher

\section{INTRODUCTION}

Animals that live in groups experience a trade-off between benefits, such as reduced predation risk, and shortcomings, such as increased intra-group competition (Booth 1995, Slotow \& Paxinos 1997, Martinez \& Marschall 1999, Krause \& Ruxton 2002). Benefits of grouping have been demonstrated in numerous reports, based on both theoretical and empirical studies on various vertebrate taxa, such as birds, fish and mammals (see Krause \& Ruxton 2002 and references therein). Major benefits are associated with increased vigilance (Morgan 1988, Lima 1995, Lima \& Bednekoff 1999), dilution effect (Pitcher 1986, Krause \& Ruxton 2002) and the confusion of predators by the group (Pitcher et al. 1982, Grand \& Dill 1999). Reduced risk allows the individuals to invest more time in foraging (Morgan 1988) and social activities, such as courtship and mating (Lima 1995). Furthermore, fish in larger groups sometimes forage further away from their refuge (Sackley \& Kaufman 1996, Grand \& Dill 1999), allowing a greater choice of preferred food (Forrester 1991).

Negative effects of grouping are mostly related to an increase of intra-group competition with increasing group size (Booth 1995, Martinez \& Marschall 1999). Slotow \& Paxinos (1997) showed a decrease in food intake in larger groups of white-crowned sparrows compared to small groups, in a trade-off with reduced predation risk. In a social spider, intra-specific competition for food was found to be a density regulation mechanism (Ulbrich \& Henschel 1999). Griffiths \& Foster (1998) reported a decrease in tadpole growth rates of 3 amphibians as a result of increased group size. A model by Rita \& Ranta (1999) predicts reduced food intake by individuals in large groups regardless of patch quality.

In the coral reef, site-attached zooplanktivorous fish are an important component of the diurnal fish community (Hobson \& Chess 1978). Feeding on zooplank- 
ton from oceanic sources, these fish have an important role in the import of allochthonous carbon and nutrients to the reef (Erez 1990). They typically live in groups that range in size from few to tens of individuals. Individuals that dare to forage farther upstream or higher above bottom usually obtain larger items and more food and therefore grow faster (Forrester 1990, 1991). On the other hand, the risk of predation increases with the distance from shelter (Slotow 1996, Sackley \& Kaufman 1996). In large groups, the average feeding success of individuals can be lower than that of individuals from small groups, due to direct competition in 'front row' foraging locations. Alternatively, lower feeding success in fish from larger groups can be a result of enhanced predator attraction to those groups and a subsequent reduction in the school's foraging time, or of a lower physiological state, resulting from enhanced infection by parasites and diseases. However, evidence for the effects of group size on the feeding success of site-attached fish is lacking. Our objective was to test the effect of group size on the feeding success in the damselfish Dascyllus marginatus.

\section{MATERIALS AND METHODS}

Study subject. Dascyllus marginatus is a common planktivorous fish in coral reefs throughout the Red Sea. It lives in social units of up to 25 individuals per group, inhabiting single colonies of branching corals, mostly Stylophora pistillata, Acropora spp., Seriatopora spinosa and Pocillopora verrucosa (Allen \& Randall 1980, Fricke 1980). At our study site, $\sim 52 \%$ of large branching corals (diameter $>35 \mathrm{~cm}$ ) are inhabited by D. marginatus (G. Koplovitz \& M. Kiflawi pers. comm.). The association of the group with its home coral lasts for at least several months (Sale 1971, Fricke 1980). The fish forage for drifting zooplankton (Fishelson et al. 1974), while swimming near $(<2 \mathrm{~m})$ their home coral, holding position against the current (Fricke 1980, Kiflawi \& Genin 1997).

The assessment of competition was based on a comparison of the amount of zooplankton prey found in the stomach of Dascyllus marginatus between fish from large and small groups. Field sampling was carried out at the coral reef off the H. Steinitz Marine Biology Laboratory, Eilat, Israel, during summer 2003 and winter 2004. Details on the local reef and environmental conditions have been given in numerous studies (see Fishelson et al. 1974, Holzman et al. 2005, and references therein).

Field work was designed based on paired sampling, in which 2 fish were caught concurrently $(<5 \mathrm{~min}$ apart), one from a small group (1 to 3 fish) and the other from a large group $(\geq 10)$. The sampling was car- ried out at the shallow section ( 3 to $8 \mathrm{~m}$ depth) of the forereef. The 2 sampled groups were always close to one another (<10 $\mathrm{m}$ apart), at identical depths and over similar topography. Therefore, we assumed that the 2 groups were exposed to similar prey flux and abiotic conditions (e.g. flow rates, light intensity, turbidity). Fish were caught by applying an anesthetic solution, injected with a syringe between the coral branches. The anesthetic substance used during 2003 was $3 \mathrm{~g}$ benzocaine-ethyl p-amino-benzoate (Sigma) in $20 \mathrm{ml}$ $99.8 \%$ ethanol diluted to a volume of $100 \mathrm{ml}$ with seawater. In 2004, we used a $20 \%$ solution of clove oil (propylene-glycol, Frutarom) in $80 \%$ ethanol. Neither substance is known to induce vomiting in fishes. After anesthetizing, the fish were caught using a hand net. On shore, the fish were put in an icebox, in order to slow prey digestion. The fish were dissected within $1 \mathrm{~h}$ of capture; the stomach was removed, and its contents were transferred to a counting tray for immediate counting under a dissecting microscope. A total of 10 pairs (20 fish) were examined, 5 pairs in summer 2003 and 5 in winter 2004. Fish from the 2 groups (small and large) did not significantly differ in size (Wilcoxon matched pairs test, $z=0.18, N S$ ). In order to exclude the effect of the large spatial and temporal difference in zooplankton density between the sampling locations of different pairs and between different sampling days, the stomach content of each fish was standardized to the deviation from the average of each pair (see 'Results').

Differences in the number of prey in the stomachs of fish from large and small groups may reflect different levels of intra-group competition or local differences in prey availability ('patchiness'), or both. In order to resolve the two, we compared the observed pair-wise differences with those expected based on a random pair-wise sampling using actual zooplankton samples taken with pumps at the same reef. Zooplankton was sampled as part of the study described by Holzman et al. (2005). Briefly, zooplankton was sampled using 4 moored vertical pump arrays, positioned 10 to $20 \mathrm{~m}$ apart, at depths of 7 to $13 \mathrm{~m}$ (for a complete description of the sampling method see Holzman et al. 2005). In order to use samples from a similar location and depth to that of our fish sampling, we used the data of Holzman et al. (2005) obtained only during the day at 0.25 , 0.75 , or $1.25 \mathrm{~m}$ above bottom from their south, north and west arrays. These samples provided an estimate of the ambient patchiness of zooplankton in the relevant zone of the water column in which the fish forage. In total, 63 samples were used to run a 'Monte Carlo simulation' as follows. From that dataset, 10 pairs of samples (from the same height above bottom) were randomly selected and assigned to 2 groups ('A' and ' $\mathrm{B}$ '). The number of cases in which the density of zoo- 
plankton in ' $\mathrm{A}$ ' was higher than in ' $\mathrm{B}$ ', as well as the average difference in zooplankton density between the 10 pairs, were noted. Random choice of the pairs was repeated 1000 times, and the frequency distribution of the 2 variables (number of times where ' $\mathrm{A}$ ' was bigger than ' $\mathrm{B}$ ' and mean difference in density) were calculated. We then compared our observed pattern to that occurring due to patchiness using a 2-tailed distribution, i.e. we calculated the probability of choosing $\mathrm{N}$ pairs out of 10, in which the density of zooplankton is higher in either ' $\mathrm{A}$ ' or ' $\mathrm{B}$ '.

The number of Dascyllus marginatus per coral was measured during summer 2002 in 159 branching corals of different sizes that hosted D. marginatus (following Fricke 1980). The survey consisted of 13 belttransects, $2 \mathrm{~m}$ wide and $50 \mathrm{~m}$ long, along the coast of Eilat. In the transects, the perimeter of each fishharboring coral was measured with a tape $( \pm 0.5 \mathrm{~cm})$ and the number of $D$. marginatus was recorded. Coral sizes were divided into $10 \mathrm{~cm}$ bins of perimeter. The maximal group size was defined as the size of the largest group found in each bin, limited to bins with $>2$ corals in each.

\section{RESULTS}

The average number of prey in the stomachs of fish from small groups ( 1 to 3 fish) was $2.1( \pm 1.27 \mathrm{SD})$ times higher than that of groups with $\geq 10$ fish (Wilcoxon paired test, $\mathrm{p}<0.025, \mathrm{n}=10$ ). The Monte Carlo simulation indicated that the above pattern was significantly different $(p<0.03)$ from that expected under random selection from the observed patchy distribution.

Despite the large variation in the stomach content (17 to 752 and 41 to 1092 prey stomach ${ }^{-1}$ in the large and small groups, respectively; Fig. 1), the ratio between the number of prey consumed by fish from small and large groups was significantly different from 1.0 (single-sample $t$-test, $\mathrm{p}<0.025, \mathrm{n}=10$ ). The average difference in zooplankton density between pairs of pumps was $86 \%( \pm 91 \%)$, ranging from 0.3 to $426 \%$ of the smaller sample. The Monte Carlo simulation indicated that the probability for this difference to exceed 2.0, as was found in the pair-wise comparison of the fish stomachs, was $<0.001$.

The most common fish-harboring corals in the reef we surveyed were Stylophora pistillata (78\%) and Acropora spp. (20\%). Weak, but significant, correlation (Pearson's $r=0.346, \mathrm{p}<0.001, \mathrm{n}=159$ ) was found between the coral perimeter and the number of fish it hosted (Fig. 2a). Nevertheless, the fish were not distributed randomly among corals, as the frequency distribution of the coral size was nearly normal (Fig. 2b), while that of the number of fish per coral was highly

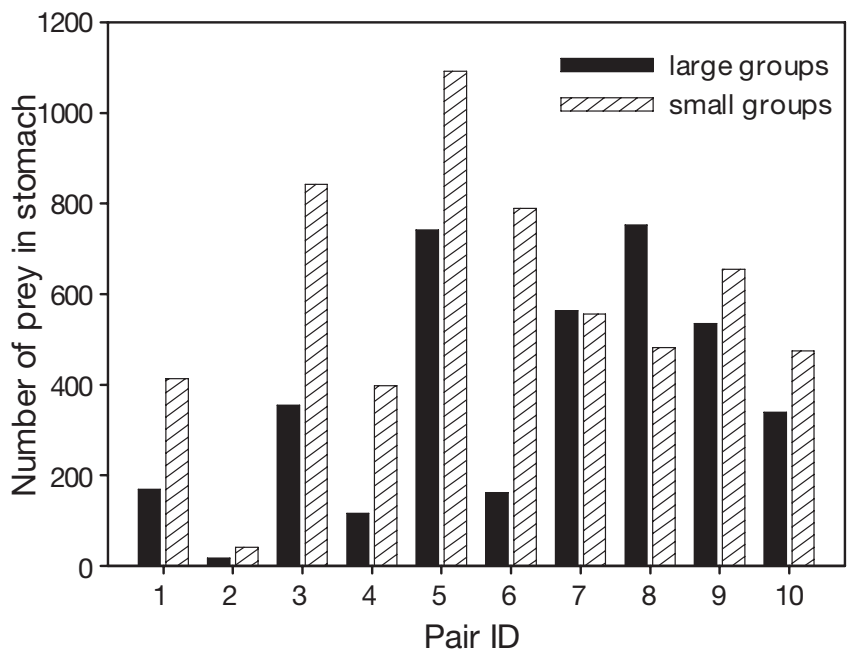

Fig. 1. Dascyllus marginatus. Number of zooplankton in the stomachs of fish from large groups ( $\geq 10$ ind. group $\left.{ }^{-1}\right)$ and small groups ( 1 to 3 ind. group ${ }^{-1}$ ) for different pairs of fish (horizontal axis) caught at 3 to $8 \mathrm{~m}$ depth in the coral reef of Eilat. The fish in each pair were caught at the same time from neighboring corals ( $<10 \mathrm{~m}$ apart) at the same depth. The difference between the 2 groups was significant (Wilcoxon matched-pairs test, $\mathrm{p}<0.025, \mathrm{n}=10$ )

skewed to the right (Fig. 2c). A random distribution would generate a ratio of 0.5 between the observed and maximal group size in each bin of coral perimeter. The observed ratio, however, was significantly $<0.5$ (ratio $=0.39$, single-sample $t$-test, $\mathrm{p}<0.03, \mathrm{df}=7$; see Table 1). This means that the fish tend to form small groups, even in large corals. This preference results in a sharp increase in the length of 'coral radius per fish' with decreasing group size (Fig. 3). About $50 \%$ of the groups consisted of 1 or 2 fish, while $100 \%$ of the corals were sufficiently large to inhabit at least 2 fish (Fig. 2b).

\section{DISCUSSION}

Stomachs of Dascyllus marginatus from small groups contained, on average, twice as much food as the stomachs of fish inhabiting large groups, suggesting the occurrence of group-size-dependent, intra-specific competition for drifting zooplankton among fish living in large groups. Fish at our site tended to form groups that were smaller than those expected under random distribution, even in large corals. Booth (1992) found that the coral's width and rugosity had no apparent effect on the number of fish settling on corals. Therefore, our estimation of coral size was determined by coral perimeter alone.

Causes for the observed reduced feeding may include several, non-mutually exclusive mechanisms. 

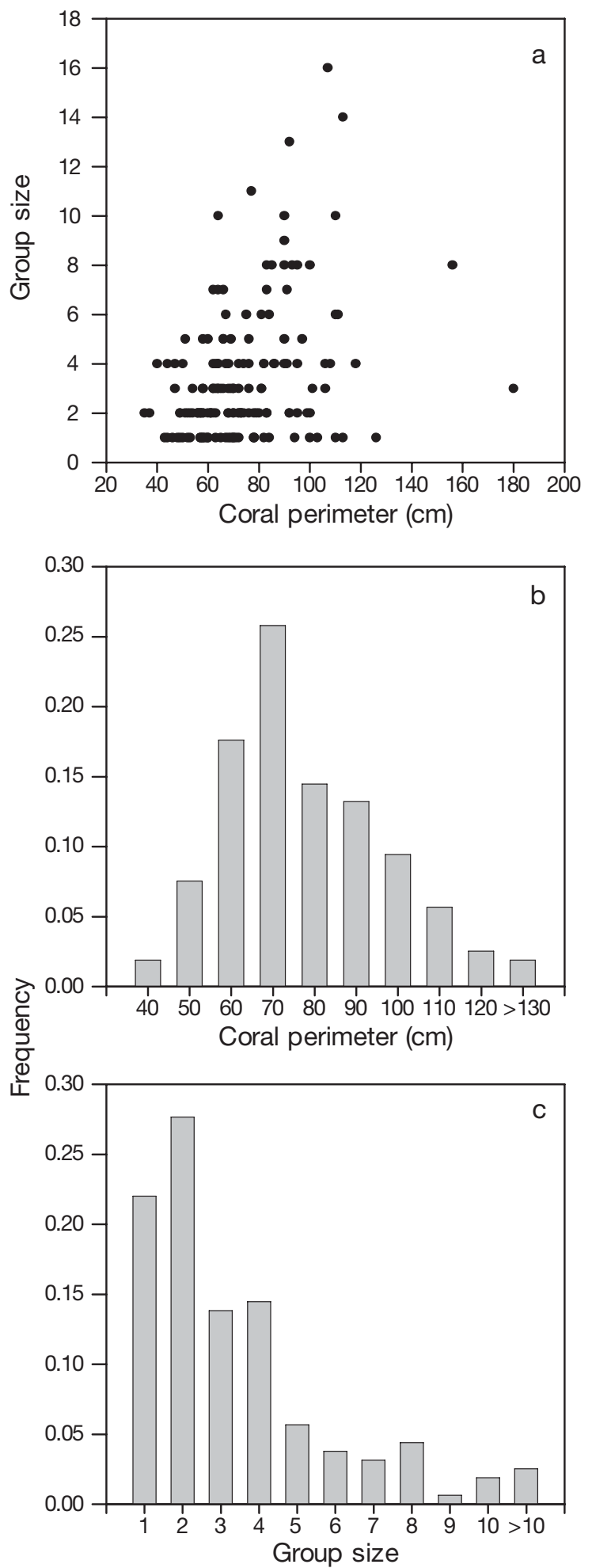

Fig. 2. Dascyllus marginatus. Group size of fish and size of their host corals (Stylophora pistillata, Acropora spp. and Pocillopora verrucosa) in Eilat. (a) Relationships between group size and coral perimeter. A weak, yet significant, correlation was observed (Pearson's $\mathrm{r}=0.35, \mathrm{p}<0.001, \mathrm{n}=159$ ).

(b) Frequency distribution of coral perimeter. (c) Frequency distribution of group size
Table 1. Survey of fish-harboring corals. Mean ratio (termed 'maximal group size' in the text) was not calculated for bins containing $<3$ corals each. NA: not applicable

\begin{tabular}{lccc}
$\begin{array}{c}\text { Coral size } \\
(\mathrm{cm})\end{array}$ & $\begin{array}{c}\text { No. of corals } \\
\text { in bin }\end{array}$ & $\begin{array}{c}\text { Max. group } \\
\text { size }\end{array}$ & $\begin{array}{c}\text { Mean ratio between } \\
\text { observed and max. } \\
\text { group size }\end{array}$ \\
\hline$<40$ & 2 & 2 & NA \\
$40-50$ & 11 & 4 & 0.545 \\
$51-60$ & 26 & 5 & 0.423 \\
$61-70$ & 39 & 10 & 0.335 \\
$71-80$ & 28 & 11 & 0.243 \\
$81-90$ & 17 & 8 & 0.492 \\
$91-100$ & 17 & 13 & 0.425 \\
$101-110$ & 9 & 16 & 0.291 \\
$111-120$ & 7 & 14 & 0.428 \\
$121-130$ & 1 & 1 & NA \\
$>130$ & 2 & 8 & NA
\end{tabular}

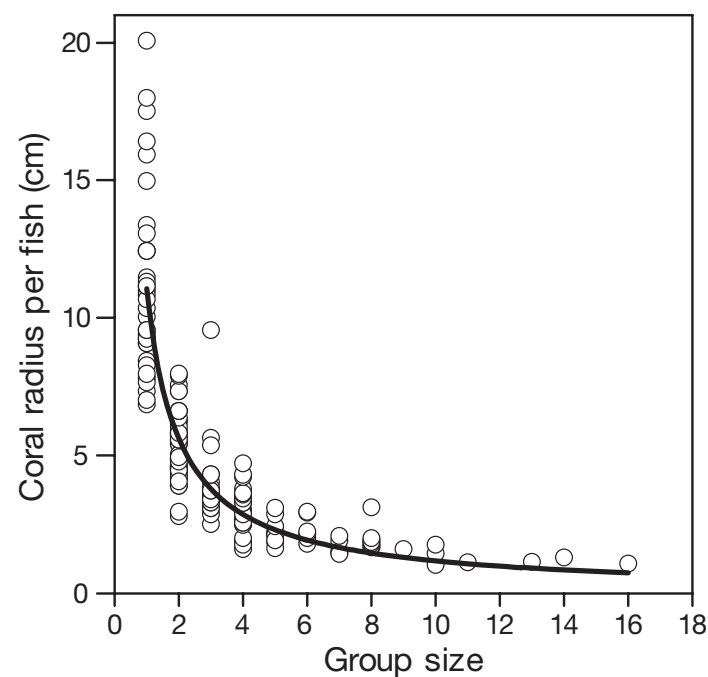

Fig. 3. Dascyllus marginatus. Relationships between 'coral radius per fish' (coral radius divided by the number of resident fish) and group size. Since the fish forage on drifting prey near the coral, the former parameter can be used as a proxy for the foraging space available for each fish (continuous line: non-linear regression $\left[y=11.06 \times x^{-0.974}, \mathrm{R}^{2}=0.77\right.$,

$$
\left.\left.F_{1,157}=546.3, \mathrm{p}<0.001\right]\right)
$$

Hierarchial status is a major factor affecting behavior of grouping fish (Forrester 1991); thus, in large groups, containing $>1$ male (sex ratio in Dascyllus marginatus is 1 male to 3.3 females; Holzberg 1973), maintaining that status is expected to be more time consuming than in small groups (Shapiro 1981). It also should be expected that more time would be invested in courting the females and in breeding, as well as in protecting the eggs from predators. Such social and reproductive activities may reduce the time invested in foraging. In addition, due to hierarchy, some individuals may be displaced to forage in a subordinate location, e.g. downstream of dominant individuals. This phenome- 
non has been termed shadow interference (Wilson 1974, Krebs \& Davies 1987, Forrester 1991). Another possible mechanism is the effect of group size on foraging space. Due to predation risk, the fish do not dare to forage far away from their shelter coral. Therefore, for site-attached fish that feed on drifting zooplankton, individuals having a wider coral radius per fish (Fig. 3) should have a larger foraging area, that is, be exposed to a higher prey flux, than fish with a smaller coral radius per fish. The trend seen in Fig. 3 strongly deviates from 'ideal free distribution' (Fretwell \& Lucas 1970), where the same coral radius per fish is expected in all group sizes. D. marginatus occupying large groups are more clumped and capture less food than those in small groups.

The 2-fold difference in feeding success between fish living in small and large groups (Fig. 1) can substantially affect the fish's growth and reproduction. It may explain why most fish were found in small groups (Fig. 2c). On the other hand, some fish did live in large groups. Our study indicates that the benefits of forming a large group, whatever they are, should be sufficiently strong to overcome the substantial shortcoming of reduced feeding.

Acknowledgements. We are grateful to the staff of IUI for the logistical support. We thank S. Ekstein, S. Sabbah, S. Manor, R. Reef, Y. Bellmaker and R. Goldshmid for help in conducting the underwater survey. R.H. thanks the Rieger Foundation for their support. This research was supported by the Israel Science Foundation (Grant No. 0397346). The experiments comply with the current laws of Israel.

\section{LITERATURE CITED}

Allen GR, Randall JE (1980) A review of the damselfishes (Teleostei: Pomacentride) of the Red Sea. Isr J Zool 29:1-98

Booth DJ (1992) Larval settlement patterns and preferences by domino damselfish Dascyllus albisella Gill. J Exp Mar Biol Ecol 155:85-104

Booth DJ (1995) Juvenile groups in a coral-reef damselfish: density-dependent effects on individual fitness and population demography. Ecology 76:91-106

Erez J (1990) On the importance of food sources in coral-reef ecosystems. In: Dubinsky Z (ed) Ecosystems of the world, Book 25. Coral reefs. Elsevier, Amsterdam, p 411-415

Fishelson L, Popper D, Avidor A (1974) Biosociology and ecology of pomacentrid fishes around the Sinai Peninsula (northern Red-Sea). J Fish Biol 6:119-133

Forrester GE (1990) Factors influencing the juvenile demography of a coral reef fish. Ecology 71:1666-1681

Forrester GE (1991) Social rank individual size and group composition as determinants of food consumption by humbug damselfish Dascyllus aruanus. Anim Behav 42:701-712

Fretwell SD, Lucas HJ Jr (1970) On territorial behaviour and other factors influencing habitat distribution in birds. Acta Biotheor 19:16-36

Editorial responsibility: Antony J. Underwood (Contributing Editor), Sydney, New South Wales, Australia
Fricke HW (1980) Control of different mating systems in a coral reef fish by one environmental factor. Anim Behav 28: 561-569

Grand TC, Dill LM (1999) The effect of group size on the foraging behaviour of juvenile coho salmon: Reduction of predation risk or increased competition? Anim Behav 58:443-451

Griffiths RA, Foster JP (1998) The effect of social interaction on tadpole activity and growth in the British anuran amphibians (Bufo bufo, B. calamita and Rana temporaria). J Zool 245:431-437

Hobson ES, Chess JR (1978) Trophic relationships among fishes and plankton in the lagoon at Enewetak Atoll, Marshall Islands. Fish Bull 1:133-153

Holzberg S (1973) Beobachtungen zur Ökologie und zum Sozialverhalten des Korallenbranches Dascyllus marginatus Rüppel (Pisces; Pomacentridae). Z Tierpsychol 33: 492-513

Holzman R, Reidenbach MA, Monismith SG, Koseff JR, Genin A (2005) Near-bottom depletion of zooplankton over a coral reef. II. Relationships with zooplankton swimming ability. Coral Reefs 24:87-94

Kiflawi M, Genin A (1997) Prey flux manipulation and the feeding rates of reef-dwelling planktivorous fish. Ecology 78 : 1062-1077

Krause J, Ruxton GD (2002) Living in groups. Oxford University Press, Oxford

Krebs JR, Davies NB (1987) An introduction to behavioral ecology, 2nd edn. Blackwell Scientific Publications, London

Lima SL (1995) Back to the basics of anti-predatory vigilance: the group-size effect. Anim Behav 49:11-20

Lima SL, Bednekoff PA (1999) Back to the basics of antipredatory vigilance: Can nonvigilant animals detect attack? Anim Behav 58:537-543

Martinez FA, Marschall EA (1999) A dynamic model of groupsize choice in the coral reef fish Dascyllus albisella. Behav Ecol 10:572-577

Morgan MJ (1988) The influence of hunger, shoal size and predator presence on foraging in bluntnose minnows. Anim Behav 36:1317-1322

Pitcher TJ (1986) Functions of shoaling behavior in teleost fishes. In: Pitcher TJ (ed) The behavior of teleost fishes. Johns Hopkins University Press, Baltimore, p 294-337

Pitcher TJ, Magurran AE, Winfield IJ (1982) Fish in larger shoals find food faster. Behav Ecol Sociobiol 10:149-151

Rita H, Ranta E (1999) An individual's gain in a foraging group. Ann Zool Fenn 36:129-138

Sackley PG, Kaufman LS (1996) Effect of predation on foraging height in a planktivorous coral reef fish, Chromis nitida. Copeia 1996:726-729

Sale PF (1971) Extremely limited home range in a coral reef fish, Dascyllus aruanus (Pisces; Pomacentridae). Copeia 1971:324-327

Shapiro D (1981) Intragroup behavioural changes and the initiation of sex reversal in a coral reef fish in the laboratory. Anim Behav 29:1199-1212

Slotow R (1996) Aggression in white-crowned sparrows: effects of distance from cover and group size. Condor 98:245-252

Slotow R, Paxinos E (1997) Intraspecific competition influences food return-predation risk trade-off by whitecrowned sparrows. Condor 99:642-650

Ulbrich K, Henschel JR (1999) Intraspecific competition in a social spider. Ecol Model 115:243-251

Wilson DS (1974) Prey capture and competition in the ant lion. Biotropica 6:187-193

Submitted: October 19, 2005; Accepted: March 20, 2006

Proofs received from author(s): September 13, 2006 